\title{
ARAŞTIRMA/RESEARCH
}

\section{Gait analysis after total knee arthroplasty: comparison of pre and postoperative characteristics}

Total diz protezi sonrasi yürüme analizi: ameliyat öncesi ve sonrasinın değerlendirilmesi

\author{
İhsan Şentürk ${ }^{1}$, Ulunay Kanatl1², Baybars Ataoğlu², Erdinç Esen² \\ ${ }^{1}$ Afyon Kocatepe University Medical Faculty, Department of Orthopedics and Traumatology, Afyonkarahisar, Turkey \\ ${ }^{2}$ Gazi University Medical Faculty, Department of Orthopedics and Traumatology, Ankara, Turkey
}

\begin{abstract}
Purpose: The aim of the present study was to investigate the difference in dynamic plantar pressure distribution changes in patients with degenerative knee arthrosis before and eight months after total knee arthroplasty (TKA) surgery.

Materials and Methods: Patients with end stage gonarthrosis admitted to our clinic for TKA constituted the study group. An EMED SF-4 pressure sensitive platform was used to quantify the barefoot plantar pressures of the participants' feet. Stance phase duration (ms), total plantar pressure $(\mathrm{N} / \mathrm{cm} 2)$ and centre of pressure $(\mathrm{CoP})$ patterns during gait were recorded preoperatively and at 8 th months postoperatively.

Results: Fifteen knees of 13 patients who underwent primary TKA were included in the study. Stance phase durations in the pre- and postoperative periods were 987 $\mathrm{ms}$ and $801.5 \mathrm{~ms}$, respectively. Total plantar pressures in the pre- and postoperative periods were $1257.75 \mathrm{~N} / \mathrm{cm} 2$ and $1436.0 \mathrm{~N} / \mathrm{cm} 2$, respectively. The difference in mediolateral plantar area was $0.69 \%$ in favor of lateral side of feet in the preoperative period and changed to $5.17 \%$ in favor of medial.

Conclusion: For the surgical realignment of the knee, the kinematic chain of the lower extremity must be considered, and gait analysis will be helpful in deciding the type of surgical treatment.
\end{abstract}

Key words: Total knee arthroplasty, gait analysis, plantar pressure distribution

\section{Öz}

Amaç: Bu çalışmada dejeneratif diz artriti olan hastaların total diz protezi (TDP) ameliyatı öncesi ve ameliyattan sekiz ay sonra ölçülen plantar basınç ölçümlerini karşılaştırmayı amaçladık.

Gereç ve Yöntem: Bu amaçla kliniğimizde gonartroz nedeniyle TDP uyguladığımız 13 hastanın 15 dizine, ameliyat öncesi ve sonrası, en az sekiz ay sonra, EMED-SF plantar basınç dağıllımı ölçüm sistemi kullanarak dinamik ayak tabanı basınç ölçümleri uyguladık. Tüm hastaların duruş fazı süreleri, toplam basınç değerleri ve COP (yürüme çizgisi) kullanılarak duruş fazında ayak basınçlarının mediale ve laterale yer değiștirmesi hesaplandi.

Bulgular: Amelivat öncesi $1257.75 \mathrm{~N} / \mathrm{cm} 2$ olan toplam duruş fazı plantar basınç, ameliyat sonrası $1436.0 \mathrm{~N} / \mathrm{cm} 2$ 'ye yükseldi. Bu fark istatistiksel olarak düşük derecede anlamı olarak tespit edildi. Ameliyat öncesi $987 \mathrm{~ms}$ olan toplam duruş fazı süresi ameliyat sonrasında $801.5 \mathrm{~ms}$ 'ye düşmüştür. Mediyolateral alan fark1 ameliyat öncesi lateral lehine \%0,69 iken ameliyat sonrası ölçümlerde bunun medial lehine $\% 5.17$ olarak değiştiği tespit edildi.

Sonuç: Dejeneratif artritte ve TDP ameliyatlarında yürüme analizi kullanılarak yapılan cerrahinin etkinliği ölçülebilmekte ve ileri çalışmalarla TDP uygulamalarının, hastaya özel planlanmasında, yararlı olacağına inanmaktayız.

Anahtar kelimeler: Total diz protezi, yürüme analizi, plantar basınç değişimi

an elderly population, most of whom are substantially affected by osteoarthritis ${ }^{1}$. Total knee arthroplasty (TKA) is the most prevalent surgical

The lengthening of life span leads to emergence of

Yazışma Adresi/Address for Correspondence: Dr. İhsan Şentürk, Afyon Kocatepe University Medical Faculty, Department of Orthopedics and Traumatology, Afyonkarahisar, Turkey E-mail: isentürk77@yahoo.com Geliş tarihi/Received: 15.06.2016 Kabul tarihi/Accepted: 03.08.2016 
procedure in end-stage knee osteoarthritis ${ }^{2}$. TKA offers pain remission, enhancement in function, and enriched life quality in the majority of patients. Nevertheless, as an artificial joint transferred to the knee, thus devoid of some features because of the altered biomechanics, the propelling force for walking forward is reduced, and a mechanical stress occurs which is associated with undesired weight distribution on prosthesis biomechanical variations that may result in early failure ${ }^{3}$.

Quantitative gait analysis is beneficial in assessing the outcomes of TKA performed even three decades earlier ${ }^{4}$. Thenceforward, it has been used progressively to assess patients with TKA ${ }^{5}$. Commonly, the gait pattern of the elderly is comparable to that of patients with TKA. This gait pattern reveals a reduction in capability to move the body forward because of weakness of lower limb joints which causes functional limitations, rest pains and functional weakness of knee extension and flexion ${ }^{5}$. The motion range in a gait cycle was already found to be limited in patients with $\mathrm{TKA}^{6}$.

Moreover, the gait pattern of patients with TKA is $16-22 \%$ less than the normal ${ }^{7}$ McClelland et al. revealed that range of motion in a gait cycle is lower in patients with TKA compared to normal individuals, and that the accompanying changes in moment patterns were related to improper stimulation of the rectus femoris and hamstrings ${ }^{8}$. It should be noted that the TKA is planned to use under normal gait patterns. Abnormal gait after TKA may cause impairment in using the prosthesis and upsurge the probability of revision surgery.

The aim of the present study was to investigate the difference in dynamic plantar pressure distribution changes in patients undergoing TKA surgery before and eight months after surgery. Our hypothesis was that the laterally concentrated preoperative plantar pressure distribution would replace medially after the procedure which is more congruent with normal individuals.

\section{MATERIALS AND METHODS}

\section{Study design}

The study was conducted in accordance with the principles of the Helsinki Declaration. A total of 15 knees of 13 consecutive patients with severe osteoarthritis who admitted to the Department of Orthopaedics and Traumatology of our university between 2013 and 2014 constituted the study group. All patients had genu varus deformities. PCLresected prostetic disagn Sigma Total Knee System was used on all of patients.

After obtaining written informed consent to participate in the study from the patients, the preoperative assessments were done. Inclusion criteria were as follows: 1 . Primary TKA surgery for primary knee osteoarthritis; 2. no other symptoms of hip and ankle pathologies while walking; 3. no other lower extremity alignment disorder or leg length discrepancy; 4. being able to walk without a cane.

Exclusion criteria were as follows: 1. postoperative complications such as deep vein thrombosis and fall; 2. neurological conditions or other diseases affecting gait ability; 3. limited walking with or without a cane postoperatively; 4. patients diagnosed with rheumatoid arthritis. All surgeries were performed by the same main surgeon, using median parapatellar approach.

\section{Outcome parameters}

The assessments were performed preoperatively and at 8 months postoperatively. An EMED SF-4 pressure sensitive platform (Novel gmbh, Munich, Germany) was used to measure the barefoot plantar pressures of the participants' feet. A $225 \times 440 \mathrm{~mm}$ dimension pressure plate, integrated into a walkway of six-meter length and a matrix of high quality capacitance sensors. The data were collected at 50 samples per second and analysed on a computer ${ }^{9,10}$. Subjects were asked to walk at their normal gait speed. All subjects took at least three successful gait cycles before touching the platform. Three stance phases of each foot were recorded. Two identical steps were selected for further analysis, and the mean of these records were used for statistical analysis.

Stance phase duration (ms), total plantar pressure $(\mathrm{N} / \mathrm{cm} 2)$ and CoP patterns during gait were recorded. CoP records the succession of instantaneous positions during the entire period of contact between foot and floor and is plotted as a sequence of points on the ground plane (Figure 1). It takes into account the displacement of load throughout the foot during the stance phase of a gait cycle and contains useful information regarding the anatomical structures acting in and on the foot during walking. 


\section{Statistical analyses}

Data were analyzed using the IBM Statistical Package for Social Sciences v.15.0 (SPSS Inc., Chicago, IL, USA). Non-parametric tests were used to determine the distribution normality of data. A P value of 0.05 or less was considered statistically significant.

\section{RESULTS}

A total of 15 knees of 13 patients were included in the study. Of the 13 patients (6 males, 7 females) whose charts were reviewed, the mean age was 62.3 years (56-72 years). The mean stance phase durations in the pre and postoperative periods were $987 \mathrm{~ms}$ and $801.5 \mathrm{~ms}$, respectively $(\mathrm{p}=0.1)$. The mean total plantar pressures in the pre- and postoperative periods were $1257.75 \mathrm{~N} / \mathrm{cm} 2$ and
1436.0 N/cm2, respectively ( $\mathrm{p}=0.09$ ). CoP patterns during gait were found to be more laterally located in the preoperative period and changed medially after the operation. Mediolateral area difference was $0.69 \%$ in favor of lateral location in the preoperative period and changed to $5.17 \%$ in favor of medial side $(p=0.09)$.

\section{DISCUSSION}

The present study aimed to investigate the difference between dynamic plantar pressure distribution changes in patients with degenerative knee arthrosis before and eight months after TKA surgery. The results of our study revealed that, although not significant, stance phase durations decreased; total plantar pressures increased; and CoP patterns changed to medial location in the postoperative period.
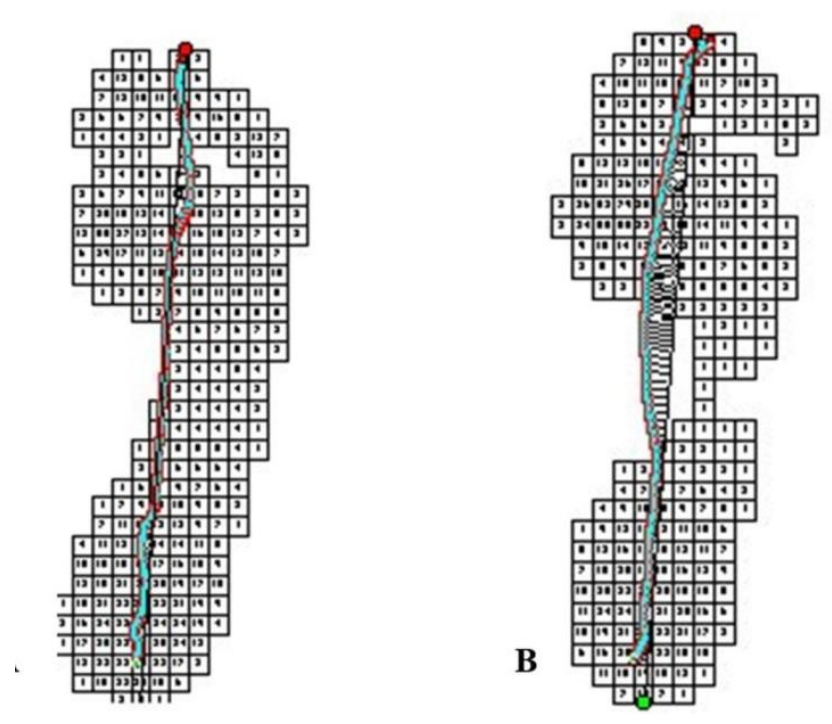

Figure 1. The curve represents the average COP spatial evolution during the whole stance phase of gait before (a) and after (b) total knee arthroplasty in the same patient.

It is essential to identify whether gait pattern is normal after TKA surgery to lessen the threat of additional impairment and deterioration of joints of the lower extremity. Normal gait pattern is welldefined as the gait pattern displayed in healthy grown-ups who do not have any injuries or surgeries of the lower extremities. Functional outcome measures are generally used after TKA to evaluate whether patients have returned to regular walking.
These types of assessment of TKA patients after surgery steadily show considerable enhancement in daily life activities ${ }^{11}$.

Gait analysis after TKA has been assessed with two systematic reviews over the past few years ${ }^{12,13}$. These have shown consistently reduced total range of motion in the knee and reduced range of flexion during stance. More recently, similar results have 
been reported for reduced knee angle during stance $^{14}$.

Benedetti et al. compared TKA patients and asymptomatic controls, and revealed reduction in two typical peaks of the knee adduction moment profile throughout the stance phase of the gait at five, twelve and twenty-four months postoperatively; however, outcomes of TKA could not be assessed since preoperative values were not recorded ${ }^{15}$. Reduction in knee adduction moments have been established pre- and post-operatively, but these reductions were not statistically significant ${ }^{16}$. In these studies, both varus and valgus knee joint configurations were involved that explains the lack of major variances. In the present study, stance phase durations in the pre- and postoperative periods were $987 \mathrm{~ms}$ and $801.5 \mathrm{~ms}$, respectively. Besides, total plantar pressures in the pre- and postoperative periods were $1257.75 \mathrm{~N} / \mathrm{cm} 2$ and $1436.0 \mathrm{~N} / \mathrm{cm} 2$, respectively.

During walking, the forward movement of the whole body centre of mass is controlled by the $\mathrm{CoP}^{17}$. Reduced CoP dislocations in TKA could lead to difficulties in sufficiently controlling dynamic steadiness. With the loss of the normal knee joint, the constancy of the artificial knee joint throughout stance becomes dominant. CoP patterns during gait were found to be more laterally located in the preoperative period. This was thought to be related to the valgus position of the subtalar joint and varus malalignment of the knee joint, which was a common finding in our patients. After realignment of the knee into slight valgus position during the surgery, the valgus position of the heel changes to valgus position as well. CoP patterns changed to medial location in the postoperative period. The reason for this change was thought to be related to the realignment of the knee and the heel. Mediolateral area difference was $0.69 \%$ in favor of lateral location in the preoperative period; however, changed to $5.17 \%$ in favor of medial location $(\mathrm{p}=0.09)$.

Characterizing the whole set of active joint modifications from the preoperative to postoperative state delivers objective data on implant function for rehabilitation and long-term prognosis. This study has several limitations. First, the sample size was small so it is difficult to generalize the results to all TKA patients. Second, we did not investigate whether the patients needed a cane during walking at hospital discharge; therefore, we could not exclude its influence on gait fluctuation.Finally, this was a single-institution study and some caution should be taken before generalizing the findings to other settings. Due to these restrictions, associations should be interpreted with caution. It seems that for the surgical realignment of the knee, like TKA and osteotomies around the knee, the kinematic chain of the lower extremity must be considered and gait analysis will be helpful in deciding the type of surgical treatment.

\section{REFERENCES}

1. Pereira D, Ramos E, Branco J. Osteoarthritis. Acta Med Port. 2015;28:99-106.

1. Fibel KH, Hillstrom HJ, Halpern BC. State-of-theArt management of knee osteoarthritis. World J Clin Cases. 2015;3:89-101.

2. Smith JW, Christensen JC, Marcus RL, LaStayo PC. Muscle force and movement variability before and after total knee arthroplasty: A review. World J Orthop. 2014;5:69-79.

3. Chao EY, Stauffer RN. Biomechanical evaluation of geometric and polycentric knee arthroplasty. Inst Mech Eng. 1974:52-60.

4. Mine T, Ihara K, Kawamura H, Kuriyama R, Date R. Gait parameters in women with bilateral osteoarthritis after unilateral versus sequential bilateral total knee arthroplasty. J Orthop Surg (Hong Kong). 2015;23:76-9.

5. Rahman J, Tang Q, Monda M, Miles J, McCarthy I. Gait assessment as a functional outcome measure in total knee arthroplasty: a cross-sectional study. BMC Musculoskelet Disord. 2015;16:66.

6. Walsh M, Woodhouse LJ, Thomas SG, Finch E. Physical impairments and functional limitations: a comparison of individuals 1 year after total knee arthroplasty with control subjects. Phys Ther. 1998;78:248-58.

7. McClelland JA, Webster KE, Feller JA. Variability of walking and other daily activities in patients with total knee replacement. Gait Posture. 2009;30:28895.

8. van der Leeden M, Dekker JH, Siemonsma PC, LekWesterhof SS, Steultjens MP. Reproducibility of plantar pressure measurements in patients with chronic arthritis: a comparison of one-step, two-step, and three-step protocols and an estimate of the number of measurements required. Foot Ankle Int. 2004:25:739-44.

9. Graft PM. The EMED system of foot pressure analysis. Clin Podiatr Med Surg. 1993;10:445-54.

10. Kane RL, Saleh KJ, Wilt TJ, Bershadsky B. The functional outcomes of total knee arthroplasty. J Bone Joint Surg Am. 2005;87:1719-24.

11. McLelland JA, Webster KE, Feller JA. Gait analysis 
following total knee replacement: a systematic review. Knee. 2007;14:253-63.

12. Milner CE. Is gait normal after total knee arthroplasty? Systematic review of the literature. J Orthop Sci. 2009;14:114-20.

13. Li K, Ackland DC, McClelland JA, Webster KE, Feller JA, de Steiger R, Pandy MG. Trunk muscle action compensates for reduced quadriceps force during walking after total knee arthroplasty. Gait Posture. 2013;38:79-85

14. Benedetti MG, Catani F, Bilotta TW, Marcacci M,
Mariani E, Giannini S. Muscle activation pattern and gait biomechanics after total knee replacement. Clin Biomech (Bristol, Avon) 2003;18:871.

15. Hilding MB, Lanshammar H, Ryd L. Knee joint loading and tibial component loosening. RSA and gait analysis in 45 osteoarthritic patients before and after TKA. J Bone Joint Surg Br. 1996;78:66.

16. Winter DA. Balance and posture in human gait. In: Winter DA, editors. Anatomy, biomechanics and control of balance during standing and walking. Waterloo Biomech. 1995:42-53. 